\title{
Ekonomi Masa Khulafa' Al Rasyidin
}

\author{
Anisa Lusiana \\ anisa02.akt@gmail.com
}

Setelah Rasulullah SAW wafat, pemerintahan dipegang oleh Khulafaurrasyidin. Dimana, perkembangan-perkembangan baru muncul dimasa itu, terutama tercermin dari kebijakannya yang berbeda antara satu khalifah dengan khalifah yang lain.. ${ }^{1}$

\section{Abu Bakar As-Shidik}

Abdullah bin Abu Quhafah al-Tamimi Atau lebih dikenal dengan nama Abu Bakar AsShidik seorang khilafah yang diangkat setelah wafatnya Nabi Muhammad SAW. Pada masa pemerintahannya yang terbilang singkat, Abu bakar menghadapi banyak masalah seperti pembangkang zakat, munculnya nabi palsu dan yang paling besar adalah kelompok yang murtad. Oleh karenanya Abu Bakar memutuskan untuk memerangi kelompok tersebut atau biasa disebut dengan perang melawan kemurtadan (Riddah). Pada masa kepempinannya dibangun pula sebuah Baitul Maal. Mendistribusikan harta kepada seluruh sahabat Rasulullah tanpa membeda-bedakan, baik itu yang terlebih dahulu memeluk islam atau kemudian, perempuan atau laki-laki maupun antara hamba dengan orang merdeka merupakan salah satu prinsip yang digunakan oleh Abu Bakar dalam mendistribusikan harta baitul maal, prinsip ini disebut prinsip kemitraan. ${ }^{2}$ Islam menawarkan sistem yang sangat moderat untuk perbaikan ekonomi masyarakat. Sistem menjadi bekal untuk menciptakan stabilitas ekonomi dan keseimbangan dan memberi peluang yang seimbang antara hak-hak alami pada setiap oran yakni kebebasan berusaha dan pada saat yang sama menjaga keseimbangan pemerataan kekayaan. ${ }^{3}$

\section{Umar Bin Khattab}

Umar bin Khattab menjadi khalifah pada hari kedua setelah Abu Bakar As-Shidik wafat, Umar menjadi Khalifah selama sepuluh tahun enam bulan dan empat hari. Umar dalam menarik jizyah mempunyai ukuran yang berbeda dengan Rasulullah saw. Rasul dalam memungut jizyah

\footnotetext{
${ }^{1}$ Fahrina Yustiasari Liri Wati dan Muhammad Rafai HA, "Pemeikiran Ekonomi Islam Pada Fase Pertama (Zyad Bin Ali dan Abu Hanifah)", JUrnal Al-Maqayyad, Vol. 3 No.1, Januari-Juni 2020, hal.106-113.

${ }^{2}$ Kharidatul Mudhiaah, "Analisis Sejarah Pemikiran Ekonomi Islam Masa Klasik", Iqtishadia, Vol.8. No.2, September 2015, hal.199-201.

${ }^{3}$ Ermawati Usman, "Ekonomi Islam Solusi Bagi Sistem Ekonomi", Jurnal Hunafa, Vol. 3 No. 2, Juni 2006, hal.146
} 
dari orang Yaman sebanyak satu dinar sedangkan Umar memungut jizyah dari penduduk Kufah 24 dirham (sama dengan 2 Dinar, pen). Kebijakan Umar dalam masalah zakat diklasifikasikan menjadi tiga bagian. Pertama, pendapat beliau seputar objek zakat. Kedua, pendapat beliau mengenai penarikan zakat. Ketiga, pendapat beliau seputar pendistribusian dan pemberdayaan zakat. ${ }^{4}$ catatan Ibnu Khaldun, Khalifah Umar mebangun lembaga baitul maal sebagai kantor keuangan negara serta membuat dokumen khusus terkait dengan baitul maal, dalam dokumen mencakup tentang pemasukan dan pembelanjaan kas negara. ${ }^{5}$

\section{Usman Bin Affan}

Khalifah Utsman bin Affan mengambil suatu langkah kebijakan tidak mengambil upah dari kantornya. Sebaliknya, ia meringankan beban pemerintah dalam hal-hal yang serius, bahkan menyimpan uangnya di bendahara negara. Kebijakan lain yang dilakukan Utsman terkait perekonomian adalah tetap mempertahankan sistem pemberian bantuan dan santunan serta memberikan sejumlah besar uang kepada masyarakat yang berbeda-beda. Meskipun meyakini prinsip persamaan dalam memenuhi kebutuhan pokok masyarakat, ia memberikan bantuan yang berbeda pada tingkat yang lebih tinggi.

\section{Ali Bin Abi Thalib}

Ali bin Abu Thalib menjadi khalifah menggantikan Utsman bin Affan, ia menjadi Khalifah selama lima tahun dan tiga bulan. Di antara kebijakan ekonomi pada masa pemerintahannya, ia menetapkan pajak terhadap para pemilik hutan sebesar 4000 dirham dan mengizinkan Ibnu Abbas, gubernur Kufah, memungut zakat terhadap sayuran segar yang akan digunakan sebagai bumbu makanan. Ada persamaan kebijakan ekonomi pada masa Ali bin Abi alib dengan khalifah sebelumnya. Pada masa Ali alokasi pengeluaran kurang lebih masih tetap sama sebagaimana halnya pada masa pemerintahan Khalifah Umar. ${ }^{6}$

${ }^{4}$ Khaerul Aqbar dan Aswar Iskandar, "Kontekstualisasi Ekonomi Zakat Dalam Mengentaskan Kemiskinan: Studi Kebijakan Zakat Umar Bin Khattab dan Perzakatan di Indonesia", Laa Maysir, Vol.6 No.2, Juli 2019, hal.229

${ }^{5}$ Risa Sari Pertiwi, dkk, "Analisis Perkembangan Praktik Baitul Maal Pada Masa Daulah Islamiyah Dan Dalam Konteks di Indonesia", Jurnal Studi Keislaman, Vol.6 No.1, Januari (2020), hal.57-58.

${ }^{6}$ Kharidatul Mudhiaah, "Analisis Sejarah Pemikiran Ekonomi Islam Masa Klasik", Iqtishadia, Vol.8. No.2, September 2015, hal.205-206. 


\section{DAFTAR PUSTAKA}

Aqbar, Khaerul, dan Aswar Iskandar. 2019. Kontekstualisasi Ekonomi Zakat Dalam Mengentaskan Kemiskinan: Studi Kebijakan Zakat Umar Bin Khattab dan Perzakatan di Indonesia. Laa Maysir, Vol.6 No.2. hal.224-246.

Mudhiaah, Kharidatul. 2015. Analisis Sejarah Pemikiran Ekonomi Islam Masa Klasik. Iqthisad, Vol.8 No.2. hal.189-210

Pertiwi, Risa Sari, dkk, Analisis Perkembangan Praktik Baitul Maal Pada Masa Daulah Islamiyah Dan Dalam Konteks di Indonesia, Jurnal Studi Keislaman, Vol.6 No.1. hal.53-71

Usman, Ermawati. 2006. Ekonomi Islam Solusi Bagi Sistem Ekonomi. Jurnal Hunafa, Vol. 3 No. 2. hal.141-148

Wati, Fahrina Yustiasari Liri, dan Muhammad Rafai HA. 2020. Pemeikiran Ekonomi Islam Pada Fase Pertama (Zyad Bin Ali dan Abu Hanifah). Jurnal Al-Maqayyad, Vol. 3 No.1. hal.106113. 